\title{
THRESHOLD-CONTROLLED THREE-STAGE HYDRAULIC BEHAVIOUR OF A MANTLED SHALLOW CARBONATE AQUIFER (TUHALA KARST AREA, NORTH ESTONIA)
}

\author{
DOLOČANJE MEJNIH VREDNOSTI TRISTOPENJSKEGA \\ HIDRAVLIČNEGA OBNAŠANJA POKRITEGA PLITVEGA \\ KARBONATNEGA VODONOSNIKA (TUHALSKI KRAS, SEVERNA \\ ESTONIJA)
}

\author{
Oliver KOIT ${ }^{1,4}$, Nataša RAVBAR ${ }^{2}$ Andres MARANDI ${ }^{3}$ \& Jaanus TERASMAA ${ }^{4}$
}

\begin{abstract}
UDC 556.34:551.44(474.2)

Oliver Koit, Nataša Ravbar, Andres Marandi \& Jaanus Terasmaa: Treshold-controlled three-stage hydraulic behaviour of a mantled shallow carbonate aquifer (Tuhala karst area, North Estonia)

As karst aquifers are often characterised by non-linear behaviour, ascertaining the turning points in their hydraulic regime may provide essential information on the functioning of the aquifer. These characteristics also apply to the Silurian-Ordovician aquifer system, composed of diverse carbonate rocks, in Estonia. The aquifer system is an important source of drinking water in northern Estonia. It also comprises the NabalaRakvere aquifer, a locally important groundwater resource that underlies the Tuhala karst area famous for an intermittently overflowing karst spring known as the Witch's Well. The water rich in humic substances of the Tuhala River recharges the Tuhala karst system, which is drained by two spring groups. In order to develop measures for the sustainable management of the aquifer in the future, the aim of this study was to enhance understanding of the hydraulic behaviour and hydrodynamic properties of the Tuhala karst system. From October 2014 to December 2016 an extensive field campaign was carried out comprising the observation of 22 surface- and groundwater monitoring points for water level and physico-chemical parameters and the performance of four quantitative tracer tests. The data obtained were evaluated in accordance with the inputoutput water level relation curves and a conceptual model of the system was set up. The results show that a strong hydraulic link exists, primarily through well-developed conduits between the recharge and discharge area of the karst system. Depending on the hydrological conditions, groundwater flow direc-
\end{abstract}

Izvleček

UDK 556.34:551.44(474.2)

Oliver Koit, Nataša Ravbar, Andres Marandi \& Jaanus Terasmaa: Določanje mejnih vrednosti tristopenjskega hidravljičnega obnašanja pokritega plitvega karbonatnega vodonosnika (Tuhalski kras, severna Estonija)

Kraški vodonosniki se pogosto obnašajo nelinearno, zato lahko $\mathrm{z}$ ugotavljanjem mejnih vrednosti v hidravličnem režimu zagotovimo bistvene informacije o delovanju vodonosnika. To velja tudi za silurijsko-ordovicijski vodonosni sistem v Estoniji, ki ga sestavljajo različne karbonatne kamnine in je pomemben vir pitne vode na severu države. Vključuje tudi vodonosnik Nabala-Rakvere, ki je lokalno pomemben vodni vir. Na tem območju se nahaja Tuhalski kras, ki je znan po občasno bruhajočem kraškem izviru Witch's Well (Čarovničin vodnjak). Tuhalski vodonosnik napaja reka Tuhala, bogata $\mathrm{z}$ huminskimi snovmi, prazni pa se skozi dve skupini izvirov. Da bi v prihodnje razvili ukrepe za trajnostno upravljanje vodonosnika, je bil namen te raziskave izboljšati razumevanje hidravličnega obnašanja in hidrodinamičnih lastnosti kraškega sistema. Od oktobra 2014 do decembra 2016 smo opravili obsežno terensko delo, ki je obsegalo spremljanje vodostajev in fizikalno-kemijskih parametrov $\mathrm{v} 23$ površinskih in podzemnih točkah ter izvedbo štirih kvantitativnih sledilnih poskusov. Pridobljene podatke smo ovrednotili na podlagi krivulje odvisnosti vhodnih in izhodnih vodnih nivojev. Vzpostavili smo konceptualni model sistema. Rezultati kažejo na obstoj močne hidravlične povezave predvsem z dobro razvitimi kanali med območji napajanja in praznjenja kraškega sistema. Odvisno od hidroloških razmer se spreminjajo smeri in hitrosti toka podzemne vode, ki znašajo od $\sim 225$ do $800 \mathrm{~m} / \mathrm{h}$. Kapaciteta prepustnosti, ki jo uravnavajo določene mejne vrednosti, in posledične in-

\footnotetext{
${ }^{1}$ School of Natural Sciences and Health, Tallinn University, Narva Road 29, 10120 Tallinn, Estonia, e-mail: koitoliver@gmail.com

${ }^{2}$ Karst Research Institute ZRC SAZU, Titov trg 2, 6230 Postojna, Slovenia and UNESCO Chair on Karst Education, University of Nova Gorica, Glavni trg 8, 5271 Vipava, Slovenia, e-mail: natasa.ravbar@zrc-sazu.si

${ }^{3}$ Institute of Applied Geosciences, Technical University of Darmstadt, Schnittsbahnstraße 9, 64287, Darmstadt, Germany, e-mail: andresmarandi@gmail.com

${ }^{4}$ Institute of Ecology, School of Natural Sciences and Health, Tallinn University, Uus-Sadama 5, 10120 Tallinn, Estonia, e-mail: jaanus.terasmaa@tlu.ee

* Corresponding author
}

Received/Prejeto: 10.03.2017 
tions vary and maximum linear flow velocities range between $\sim 225$ and $800 \mathrm{~m} / \mathrm{h}$. A threshold-controlled throughput capacity and interaction with the adjacent aquifer cause imbalances between the input and output discharges of the karst system. Tracer tests coupled with surface and groundwater level relation curve analysis allowed the specification of flow threshold conditions for the Witch's Well spring group and the overflow threshold for the Witch's Well, among other key hydrological events. The hydraulic regime of the karst system was divided into three stages, each with differing threshold controls and hydrodynamic characteristics.

Key words: karst system, shallow carbonate aquifer, monitoring, tracer test, water level relation curve, threshold, overflow. terakcije s sosednjimi vodonosniki povzročajo neravnovesja med vhodnimi in izhodnimi pretočnimi vrednostmi kraškega sistema. Združevanje rezultatov sledilnih poskusov $\mathrm{z}$ analizo krivulje odvisnosti površinskih in podzemnih vodostajev nam je omogočilo, da smo določili mejne pretočne vrednosti izvira Witch's Well in druge ključne hidrološke dogodke. Hidravlični režim kraškega sistema smo razdelili na tri faze, od katerih ima vsaka določene mejne vrednosti in hidrodinamične lastnosti.

Ključne besede: kraški sistem, plitvi karbonatni vodonosnik, monitoring, sledilni poskus, krivulja odvisnosti vodnih nivojev, prag, preliv.

\section{INTRODUCTION}

It has been estimated that between $20 \%$ and $25 \%$ of the global population relies on groundwater derived from karst aquifers (Ford \& Williams 2007), which can be an abundant source of good-quality groundwater (Smart \& Worthington 2004; Stevanović 2015). As karst aquifers usually feature heterogeneous, complex hydrogeological characteristics and rapid infiltration and transport velocities due to solution-enhanced porosity, their behaviour is highly contingent on the respective hydrological conditions. Furthermore, unimpeded and poorly filtered prevailing channel-type flow raises the vulnerability level of such aquifers to the highest levels. Consequently, their characterisation and sustainable management pose many scientific and practical challenges (Bonacci 1987; Bakalowicz 2005; Ford \& Williams 2007; Goldscheider et al. 2007; Ravbar 2013).

Water drainage patterns are particularly intricate in the case of binary and/or shallow karst aquifers whose functioning may be influenced by non-linearities and threshold effects (Zehe \& Sivapalan 2009; Birk et al. 2014; Chinarro 2014; Calligaris et al. 2016). Consequently, different types of surface-groundwater interaction, variable flow directions and thus shifting groundwater divides as well as changing flow velocities and the manner of flow (surface vs underground, laminar vs turbulent, openchannel vs pressurised) ensue. Furthermore, the respective hydrological conditions may have a major impact on the contaminant transport and groundwater quality (Kulakowski 2010; Naughton et al. 2012; Ravbar et al. 2012; Mayaud et al. 2014; Smith et al. 2015; McCormack et al. 2016). For accurate understanding, interpretation and management of such aquifers it is therefore crucial to recognise the circumstances and assess the threshold values that lead to changes in drainage patterns.

Analyses of karst spring hydrographs combined with physico-chemical parameters of water are frequently used to acquire information on the structure and behaviour of karst aquifers, on different recharge mechanisms and on contamination problems (e.g. Ryan \& Meiman 1996; Fiorillo et al. 2007; Herman et al. 2008; Petrella et al. 2009; Mudarra \& Andreo 2011; Birk et al. 2014). Natural or artificial tracers can provide additional information on water flow characteristics and matter transport (Herczeg et al. 1997; Gabrovšek et al. 2010; Reed et al. 2010; Ravbar et al. 2012; Bonacci \& Andrić 2015). Numerical modelling and computational approaches have made significant progress in usefulness and application regarding thresholds in karst hydrogeology (Gill et al. 2013; Mayaud et al. 2014; Schmidt et al. 2014; Meng et al. 2015). However, an initial conceptual understanding of the area of interest is a prerequisite for further numerical modelling (Davis \& Putnam 2013).

This study focuses on northern Estonia, a region that hosts extensive unconfined shallow aquifers in Silurian-Ordovician carbonate rocks (which together form the large Silurian-Ordovician aquifer system). In Estonia, this aquifer constitutes an important and often the only source of potable water (i.e. $85 \%$ of the total and $33 \%$ of domestic groundwater consumption) (Perens \& Vallner 1997; Karro et al. 2009; Olesk 2016). The $30 \mathrm{~m}$ (or in rare occasions up to $75 \mathrm{~m}$ ) thick top section of the flat-lying carbonate bedrock is usually fractured and karstified (Heinsalu 1977; Perens \& Vallner 1997; Karst ja allikad Pandiveres 2002). Due to the relatively flat topography, most intensive karstification occurs near bedrock escarpments or hillocks that provide a crucial gradient for circulation. Frequently, shallow karst aquifers drain acidic humic-rich streams originating from bogs and are influenced by considerable surface-groundwater interaction. Private households commonly draw the groundwater through shallow drilled or dug wells. 
The Tuhala karst area (TKA) is a textbook example of intensive interaction between a humic-rich river and a shallow karst aquifer. It is one of the most remarkable karst areas in Estonia, known primarily for a scenic intermittent overflowing karst spring known as the Witch's Well (WW). The humic-rich allogenic Tuhala River sinks into the karst system hosted by a shallow carbonate aquifer that is drawn by tens of households inhabiting the study area. However, the abstraction rates of local households are generally inadequate to significantly affect the water budget. Comprehensive studies from the past by Maastik (1973), Laas \& Jürine (1974), Heinsalu (1978), Sooäär (1980) have provided crucial geological and hydrological base knowledge about the functioning of the TKA. A fresh attempt to characterise the groundwater flow and hydrodynamic properties of the TKA system was recently made by Koit (2016).

In recent years many conflicting interests have surfaced regarding the commercial use of karst areas in Es- tonia and concerns have been raised over the threat to water resources and the issue of their protection. The TKA has repeatedly fallen in the potential sphere of influence of planned economic developments, thus has frequently been the focal point of disputes. In this study, an integrative approach consisting of field observations, hydrometrical and physico-chemical (water electrical conductivity and temperature) monitoring, tracer tests combined with an input-output relation curve construction was applied. The expected outcome of the approach was to identify and determine the threshold flow conditions and hydraulic behaviour of the TKA and further facilitate the addressing of the challenging problems of groundwater management. The emphasis was on determining the activation and overflow threshold conditions of the WW and the rest of its intermittent spring group. Finally, an additional aim of the study was to promote research into and knowledge of the little-known Estonian karst.

\section{STUDY AREA}

The Tuhala karst area (TKA), a karst landscape reserve which is a part of Nabala-Tuhala Nature Reserve formed in 2014 , covers $1.8 \mathrm{~km}^{2}$ and is located in the village of Kata in northern Estonia (Fig. 1). The TKA is situated in the transition zone of the Baltic sea maritime and continental ( $\mathrm{Cfb}$ and Dfb according to Köppen-Geiger climate classification (Kottek et al. 2006)) climate regions. The average annual temperature in Estonia is $5.2{ }^{\circ} \mathrm{C}$. As the average annual amount of precipitation according to the Kuusiku and Tallinn-Harku weather stations (for locations see Fig. 1) of the Estonian Weather Service $(735 \mathrm{~mm})$ exceeds the average annual evapotranspiration (430-450 mm; Kink 2007), humid conditions prevail.

Estonia is situated in the NW part of the East-European platform of Neoproterozoic and Paleozoic (from Ediacaran to Devonian) sedimentary rocks slightly inclined towards south (Raukas 1997; Suuroja et al. 2003). The TKA is located in the middle of the Harju Plateau (Fig. 1) of Ordovician and Silurian carbonate rocks. A layer of Quaternary deposits with a thickness of 2-9.2 m mantles the bedrock (Fig. 1), while in places the cover can be thin (less than $1 \mathrm{~m}$ ) or absent. The TKA's Quaternary cover consists mainly of Late Weichselian glacial tills, overlain in the N-NE part by the glaciolacustrine deposits of the Baltic Ice Lake. Holocene alluvial loams or peat deposits may be present along the Tuhala River (Laas \& Jürine 1974; Heinsalu 1978; Sooäär 1980).
The topmost part of the bedrock (Fig. 1) is composed of Katian Stage (Upper Ordovician) carbonate rocks. The bedrock elevation is greatest at the southwestern margin of the TKA (55-60 m a.s.l.) and decreases (40 $\mathrm{m}$ a.s.l.) towards the buried bedrock valley system of the Pirita River in the N-NE (not shown on the map). The upper section, fractured and karstified and approximately $20 \mathrm{~m}$ thick, comprises the relatively pure, aphanitic and sometimes dolomitised limestones of the Kõrgessaare and Saunja formations, while the lower, less karstified section consists of more clayey limestones of the Paekna formation (Laas \& Jürine 1974; Heinsalu 1978; Suuroja et al. 2003).

The hydrogeological contexts of the TKA are determined by the characteristics of the overlying terrigenous Quaternary aquifer and the underlying fractured and karstified Nabala-Rakvere aquifer of the SilurianOrdovician aquifer system (Perens 1998), which spread throughout the study area. The Nabala-Rakvere aquifer usually recharges from the overlying Quaternary aquifer, although in places the overlying loam till may act as a weak upper aquitard $(\mathrm{K}=0.001 \mathrm{~m} / \mathrm{d})$ and cause pressurisation of the karst groundwater. The argillaceous limestones and marls of the Hirmuse formation (not shown on the cross-section) form the lower confining unit for the shallow Nabala-Rakvere aquifer (Vallner 1996).

The Nabala-Rakvere aquifer is divided into a waterrich upper sublayer (mean transmissivity $390-540 \mathrm{~m}^{2} / \mathrm{d}$ ) 


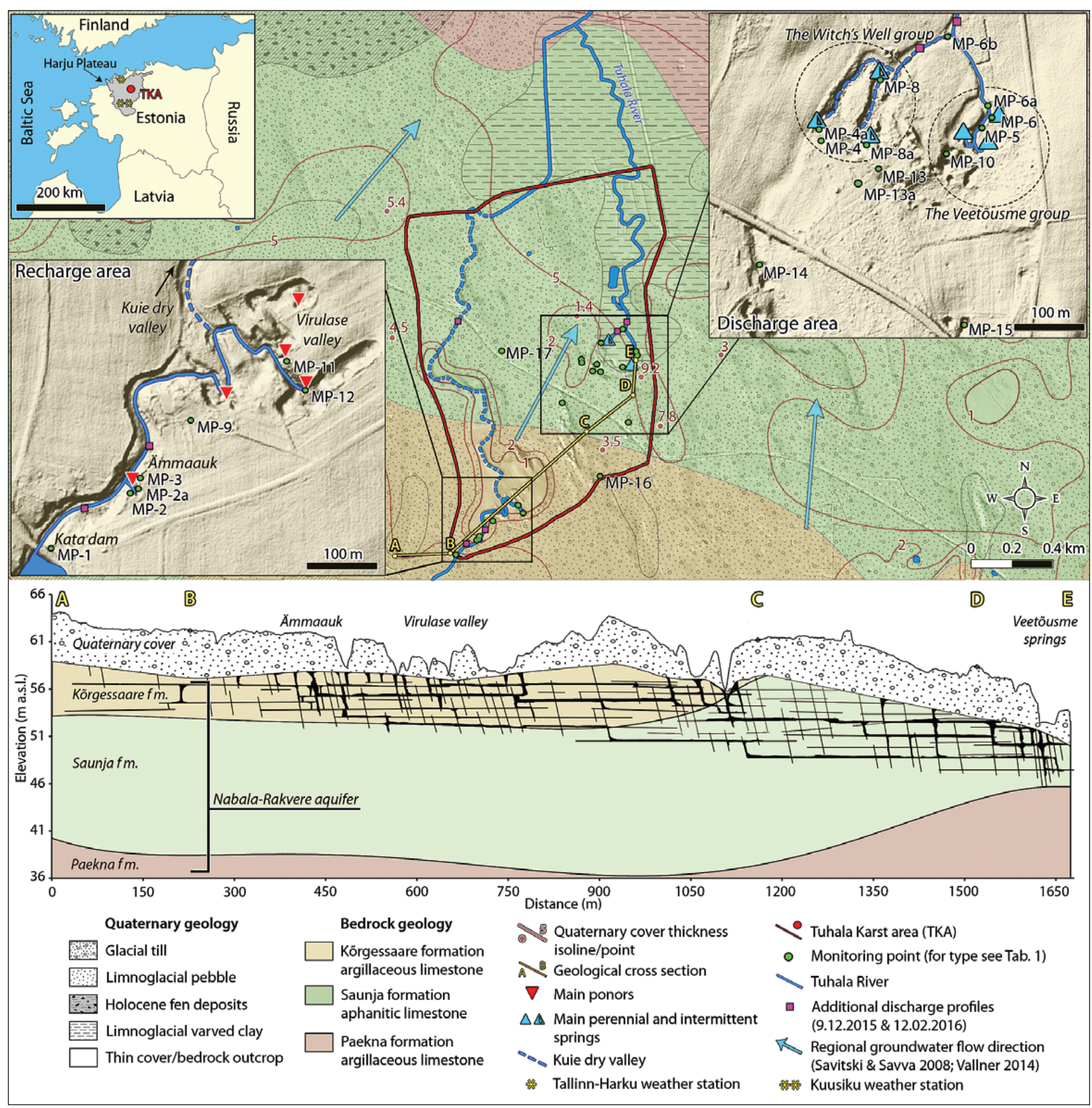

Fig. 1: "Location, geology and profile of the study area featuring the geological units relevant to the TKA system." The map shows the survey section of the Tuhala River and the Kuie dry valley, the locations of permanent and temporary monitoring points, and the main ponors and springs of the Tuhala karst system. The cross-section features an interpretation of the probable extent and spread of the karstified fracture network based on borehole cross-sections and field observations. Raw LIDAR data (resolution $5 x 5 \mathrm{~m}$ ), geographical and geological base maps were provided by the Estonian Land Board. The thickness of Quaternary cover was calculated and interpolated based on the difference between the known cross-sections of boreholes in TKA and the DEM surface.

comprising the Saunja formation (and the Kõrgessaare formation, if present) and the upper part of the Paekna formation, and a less permeable lower sublayer (mean transmissivity $48 \mathrm{~m}^{2} / \mathrm{d}$ ) comprising the lower section of the Paekna formation (Petersell et al. 2011). In areas of tectonic disturbances, including in the TKA, transmis- sivity may exceed $1000 \mathrm{~m}^{2} / \mathrm{s}$ (Perens \& Vallner 1997). According to the well $\log$ of a $17.6 \mathrm{~m}$ deep borehole in point D of Fig. 1 cross-section, the bedrock may be fractured and karstified to a depth of $13.5 \mathrm{~m}$. The average thickness of the epikarst in TKA is $1-3 \mathrm{~m}$, but in places can be up to $5 \mathrm{~m}$ thick (Heinsalu 1978; Suuroja et al. 2003). 
According to Heinsalu (1978), surface water levels (WL) and shallow groundwater levels (GWL) may range from $60 \mathrm{~m}$ a.s.l. in the southern part of the TKA to $50 \mathrm{~m}$ a.s.l. in the NE margin of the TKA. The regional groundwater flow direction in TKA is from SW to NE (Savitski \& Savva 2008; Vallner 2014).

The TKA is located on the lower course of the Tuhala River, which is a left tributary of the Pirita River (not shown on the map) and thus belongs to the drainage basin of the Gulf of Finland. The $25 \mathrm{~km}$ long river Tuhala has a surface drainage basin of $112 \mathrm{~km}^{2}$. This allogenic humic-rich river rises in the Leva bog, situated approximately $10 \mathrm{~km}$ southeast of TKA (not shown on the map). According to the discharge $(\mathrm{Q})$ hydrographs of the Tuhala River from 1983 to 1986, the Q in MP-1 (Fig. 1) has ranged from 0.01 to $10 \mathrm{~m}^{3} / \mathrm{s}$.

The Tuhala River sinks underground near the Kata village and discharges again after $1-1.5 \mathrm{~km}$ of underground flow in two groups of springs located in the $\mathrm{N}$ and NE outskirts of the village. According to Laas \& Jürine (1974) and Heinsalu (1978), the TKA has developed on the basis of NE-SW, NW-SE and N-S oriented fracture zones. It is predominantly fed by the Tuhala River, although an unspecified portion of recharge is obtained from the adjacent aquifer and infiltrating precipitation. Under low water conditions, most of the Tuhala River sinks approximately $100 \mathrm{~m}$ downstream from the Kata dam, when it reaches a set of NW-SE oriented grikes in the right riverbank. As the sinking capacity of the grike zone is exceeded, the river makes its way to the complex NE-SW and NW-SE feature based blind valley system of Virulase, where it sinks terminally in numerous ponors. If the $\mathrm{Q}$ of the river exceeds the sinking capacity of the ponors, the valley is flooded and the excess water begins to flow north along the $1.2 \mathrm{~km}$ Kuie dry valley to its confluence with the Tuhala River farther north. Heinsalu (1978) and Sooäär (1980) suggested that the dry valley used to be the primary flow path for the
Tuhala River for some time after the retreat of the last continental glacier.

The Tuhala River emerges again in two groups of perennial and intermittent springs located in the $\mathrm{N}$ and NE part of the TKA. The main discharge area comprises the perennial spring group of Veetõusme $\left(\mathrm{Q}_{\max }=2.6-3 \mathrm{~m}^{3} / \mathrm{s}\right.$; Heinsalu 1978; Koit 2016) and the intermittent spring group of the Witch's Well (WW) $\left(\mathrm{Q}_{\max }=1.1 \mathrm{~m}^{3} / \mathrm{s}\right.$; Heinsalu 1978; Koit 2016). The WW (MP-4) is a $2.4 \mathrm{~m}$ deep shallow well dug in the bottom of a suffosion doline, where an intermittent spring operates during medium to high GWLs. The drying of the WW was not witnessed during the monitoring period, the lowest GWL measured was $53.44 \mathrm{~m}$ a.s.l. in October 2015. Before the well curbs were built on top of the WW spring during the 1930s to protect the water from cattle faecal pollution, it was probably in some ways similar to the adjacent suffosion sinkhole (MP-4a in Fig. 1) that functions as an estavelle. The WW and the estavelle are situated in the bottom of a gentle depression formed in Quaternary cover. The WW is known for overflowing above its curbs during spring thaws and flood events, and has since become a symbol of nature tourism.

Before the WW starts to overflow, the MP-4a estavelle and at least four smaller and lower positioned intermittent springs of the group (including MP-8 and MP-8a) start to discharge. The location of the Veetõusme and WW spring groups with respect to the recharge area is determined by the major NE-SW regional fracture zone. According to Heinsalu (1978), there are also at least four intermittent springs in the Kuie dry valley between the recharge area and the mouth of the dry valley that could be related to an $\mathrm{N}-\mathrm{S}$ fracture zone. However, it was stated by the local people that the springs of the Kuie valley operate only shortly before the surface flow is established during high water level conditions. Thus, the springs were not continuously monitored during this study.

\section{METHODS}

\section{SURFACE- AND GROUNDWATER MONITORING}

Five surface water level and six groundwater level monitoring points (type WLP and GWLP, respectively, in Tab. 1) were set up at the key points of the TKA (Fig. 1). In surface water monitoring points the WL datum rods were hammered into the ground in the measured crosssections. The tips of the datum rods were positioned using a Leica GNSS device. The relative height of the WL was measured with respect to the tip of the datum rod. GWL levels were measured with respect to the top of the well casing by using a standard dipper. The manual monitoring of WL/GWL took place on average three times a month during the study period of October 2014December 2016.

Over the course of the study period the Qs of the Tuhala River (in 6 monitoring points) were measured six times (hollow markers in Fig. 2) during different hy- 
Tab. 1: List of monitoring points. For locations see Fig. 1.

\begin{tabular}{|c|c|c|c|}
\hline $\begin{array}{l}\text { Monitoring } \\
\text { point }\end{array}$ & Name & Type* & $\begin{array}{c}\text { Datum } \\
\text { Elevation } \\
\text { (m a.s.l.) }\end{array}$ \\
\hline MP-1 & Kata dam & WLP & 57.37 \\
\hline MP-2 & Upstream from Ämmaauk & WLP & 58.4 \\
\hline MP-2a & Ämmaauk ponor & IP & 58.4 \\
\hline MP-3 & $\begin{array}{l}\text { Downstream from } \\
\text { Ämmaauk }\end{array}$ & WLP & 58.52 \\
\hline MP-4 & The Witch's Well (WW) & GWLP; SP & 56.39 \\
\hline MP-4a & The WW estavelle & SP & 54.45 \\
\hline MP-5 & $\begin{array}{l}\text { The Veetõusme springs } \\
1 \& 2\end{array}$ & WLP; SP & 54.45 \\
\hline MP-6 & The Veetõusme springs 3 & WLP; SP & 54.35 \\
\hline MP-6a & $\begin{array}{l}\text { Downstream from the } \\
\text { Veetõusme springs } 1\end{array}$ & SP & 54.2 \\
\hline MP-6b & $\begin{array}{l}\text { Downstream from the } \\
\text { Veetõusme springs } 2\end{array}$ & SP & 54.14 \\
\hline MP-8 & $\begin{array}{l}\text { Intermittent spring } 1 \\
\text { in the WW group }\end{array}$ & SP & 54.57 \\
\hline MP-8a & $\begin{array}{l}\text { Intermittent spring } 2 \\
\text { in the WW group }\end{array}$ & SP & 55.24 \\
\hline MP-9 & Kihu drilled well & GWLP; SP & 60.95 \\
\hline MP-10 & Karst window & SP & 54.7 \\
\hline MP-11 & Virulase cave & IP & 56.93 \\
\hline MP-12 & Kirstuauk ponor & IP & 55.27 \\
\hline MP-13 & Sulu drilled well 1 & SP & 59.26 \\
\hline MP-13a & Sulu drilled well 2 & GWLP & 57.43 \\
\hline MP-14 & Polli dug well & SP & 57.11 \\
\hline MP-15 & Nogliku dug well & GWLP; SP & 57.51 \\
\hline MP-16 & Kata church drilled well & GWLP & 64 \\
\hline MP-17 & The "kinked" drilled well & GWLP & 61.9 \\
\hline
\end{tabular}

* WLP-water level monitoring point; GWLP-groundwater level monitoring point; IP-tracer injection point; SP-tracer sampling point

drological conditions. Q measurements were carried out in additional locations during flood events in December 2015 and February 2016 (purple square markers in Fig. 1). Flow velocity or $\mathrm{Q}$ measurements were carried out using either a simple General Oceanics 2030 current meter or SonTek FlowTracker ADV (Acoustic Doppler Velocimeter) and a boat-mounted SonTek RiverSurveyor S5 ADP (Acoustic Doppler Profiler). Based on the measured Qs and WL monitoring data, WL-Q rating curves were compiled for each monitoring point.

Occasionally electrical conductivity (EC) and temperature $(\mathrm{T})$ readings were obtained in all monitoring points using YSI 556 MPS, YSI Professional Plus and YSI 600XLM, Hanna pHep ${ }^{\circledR}$ or XS Instruments PC 5 KIT. In the later phase of the study, MP-4 \& MP-13a (since 23 September 2016), MP-9 (since 18 November 2016) and MP-17 (since 20 December 2016) were equipped with automatic GWL, EC and T data loggers (Onset $\mathrm{HOBO}$
U20L-02 and U24-001). Another U20L-02 was deployed in the study area for barometric compensation. For data loggers' specifications see Onset (2017). The monitoring interval for the automatic loggers was set to 30 min. Hourly precipitation data from the Kuusiku and Tallinn-Harku weather stations (for locations see Fig. 1) was provided by the Estonian Weather Service.

\section{TRACER TESTS}

During the study period, three quantitative groundwater tracer tests with sodium chloride $(\mathrm{NaCl})$ and one quantitative/qualitative multitracer test with uranine (URA) (CAS RN 518-47-8) and naphthionate (NAP) (CAS RN 130-13-2) were conducted. The quantities of tracers were chosen according to the desired target concentration at the springs, linear distance, hydrological conditions and recommendations from Benischke et al. (2007) and Kogovšek \& Liu (2011). The selection of injection and sampling points were based on the previous thorough study of Heinsalu (1978), tracer test aims and respective hydrological conditions. The basic information is summarised in Tab. 2.

Hereinafter, for better comparison, all described events are associated to hydrological conditions in MP-1. On 27 February 2015 (MP-1 WL=58.19 m a.s.1.; $\mathrm{Q}=1.28 \mathrm{~m}^{3} / \mathrm{s}$ ), a tracer test (TT-1) with $300 \mathrm{~kg}$ of $\mathrm{NaCl}$ was carried out. Due to the availability of two EC monitoring devices (YSI $556 \mathrm{MPS}$ and YSI 600XLM), the confluence of the Veetõusme springs (MP-6a) and the WW (MP-4) (Fig. 1; Tab. 2) were chosen as the sampling points. Instantaneous injection into the Ämmaauk ponor (MP-2a) took place at 15:10. EC readings were recorded every 5 minutes and sampling continued until 10:38 on 28 February 2015.

On 7 March 2015 (MP-1 WL=58.35 m a.s.l.; $\mathrm{Q}=1.63 \mathrm{~m}^{3} / \mathrm{s}$ ), a tracer test (TT-2) with $200 \mathrm{~kg}$ of $\mathrm{NaCl}$ was conducted. Instantaneous injection into MP-11 took place at 13:50. Sampling was carried out in MP-6b (YSI Professional Plus), slightly downstream from the former MP-6a (Fig. 1). MP-4 was also sampled, but due to the device (YSI 600XLM) malfunction, no usable data was acquired. Sampling (2 min sampling interval) continued until 21:38 on 7 March 2015.

A multi tracer test (TT-3) with $50 \mathrm{~g}$ of URA and $250 \mathrm{~g}$ of NAP was conducted on 12 December 2015 (MP-1 WL=58.41 $\mathrm{m}$ a.s.1.; $\mathrm{Q}=1.75 \mathrm{~m}^{3} / \mathrm{s}$ ). Instantaneous injection of $50 \mathrm{~g}$ of URA into MP-2a took place at 10:44. As MP-2a was submerged at that time, injection was executed through a $4 \mathrm{~m}$ long plastic pipe that was inserted into the submerged ponor. As the WL had dropped since the day before, the flow connection between the river and MP-11 had ceased. In order to provide more water to the Virulase valley, the Kata dam was temporarily lowered. 
THRESHOLD-CONTROLLED THREE-STAGE HYDRAULIC BEHAVIOUR OF A MANTLED SHALLOW CARBONATE AQUIFER ...

Tab. 2: Tracer test injection points, type and amount of tracer, hydrological conditions and monitoring strategy.

\begin{tabular}{|c|c|c|c|c|c|c|c|c|}
\hline \multirow[t]{2}{*}{ Tracer test } & \multirow[t]{2}{*}{ Date } & \multirow{2}{*}{$\begin{array}{l}\text { Hydrological conditions } \\
\text { in MP-1 }\left(\mathrm{m}^{3} / \mathrm{s}\right)\end{array}$} & \multicolumn{2}{|c|}{ Tracer } & \multirow{2}{*}{$\begin{array}{c}\text { Injection } \\
\text { point }\end{array}$} & \multicolumn{3}{|c|}{ Sampling } \\
\hline & & & Type & Quantity & & Point & Frequency & Duration (h) \\
\hline \multirow{2}{*}{ TT-1 } & \multirow{2}{*}{27 Feb 2015} & \multirow{2}{*}{1.28 (medium) } & \multirow{2}{*}{$\mathrm{NaCl}$} & \multirow{2}{*}{300 kg } & \multirow{2}{*}{ MP-2a } & MP-6a & \multirow{2}{*}{$5 \mathrm{~min}$} & \multirow{2}{*}{19.50} \\
\hline & & & & & & MP-4 & & \\
\hline \multirow{2}{*}{ TT-2 } & \multirow{2}{*}{7 Mar 2015} & \multirow{2}{*}{1.63 (medium) } & \multirow{2}{*}{$\mathrm{NaCl}$} & \multirow{2}{*}{200 kg } & \multirow{2}{*}{ MP-11 } & $M p-6 b$ & \multirow{2}{*}{$2 \min$} & \multirow{2}{*}{8} \\
\hline & & & & & & MP-4 & & \\
\hline \multirow{8}{*}{ TT-3 } & \multirow{8}{*}{12 Dec 2015} & \multirow{8}{*}{1.75 (medium) } & \multirow{4}{*}{ URA } & \multirow{4}{*}{$50 \mathrm{~g}$} & \multirow{4}{*}{ MP-2a } & MP-4 & \multirow{8}{*}{$\begin{array}{c}\text { Initially } \\
\text { every } 15 \\
\text { min, later } \\
\text { every } 30 \\
\text { min, } 60 \text { min } \\
+2 x \text { after } \\
24 \mathrm{~h}\end{array}$} & \multirow{8}{*}{73} \\
\hline & & & & & & MP-5 & & \\
\hline & & & & & & MP-6 & & \\
\hline & & & & & & MP-8 & & \\
\hline & & & \multirow{4}{*}{ NAP } & \multirow{4}{*}{$250 \mathrm{~g}$} & \multirow{4}{*}{ MP-12 } & MP-10 & & \\
\hline & & & & & & MP-13 & & \\
\hline & & & & & & MP-14 & & \\
\hline & & & & & & MP-15 & & \\
\hline \multirow{4}{*}{ TT-4 } & \multirow{4}{*}{21 Nov 2016} & \multirow{4}{*}{2.75 (medium-high) } & & & & MP-5 & $5 \mathrm{~min}$ & 20 \\
\hline & & & $\mathrm{NaCl}$ & $200 \mathrm{~kg}$ & MP-2a & MP-8a & $5 \mathrm{~min}$ & 20 \\
\hline & & & IVach & $200 \mathrm{ng}$ & $\sqrt{111}-2 a$ & MP-4 & $30 \mathrm{~min}$ & 236 \\
\hline & & & & & & MP-9 & & \\
\hline
\end{tabular}

The additional lowering did not provide enough water to re-establish flow to MP-11, so NAP was injected into an active ponor (MP-12) near MP-11. The instantaneous injection of NAP into MP-12 took place at 12:17. The interval for manual sampling with $100 \mathrm{ml}$ plastic bottles was every 15 minutes for the first four hours, then every 30 minutes for the next two hours and finally every hour until 18:40 the same day. Another sample was taken approximately $24 \mathrm{~h}$ later on 13 December and from some of the sampling points, once more on 15 December. Prior to the test, blind samples were taken from all of the sampling points. The samples were handled and preserved as recommended by Benischke et al. (2007). As the sampling interval of 15 minutes during TT- 3 was quite long, the average time in-between the last sample with background concentration and the first sample of detection was calculated when assessing the first detection times of tracers.

Quantitative analysis of the fluorescent dye samples and the calibration curve development was carried out in the laboratory of the Karst Research Institute, Research Centre of the Slovenian Academy of Sciences and Arts (Postojna, Slovenia) on 11 April 2016. An LS 45 Perkin Elmer fluorescence spectrometer was used, implement- ing the following values: $\mathrm{E}_{\mathrm{ex}}=491 \mathrm{~nm}, \mathrm{E}_{\mathrm{em}}=512 \mathrm{~nm}$ for URA and $\mathrm{E}_{\mathrm{ex}}=320 \mathrm{~nm}, \mathrm{E}_{\mathrm{em}}=430 \mathrm{~nm}$ for NAP.

On 21 November 2016 (MP-1 WL=58.81 m a.s.l.; $\mathrm{Q}=2.75 \mathrm{~m}^{3} / \mathrm{s}$ ) a tracer test (TT-4) with $200 \mathrm{~kg}$ of $\mathrm{NaCl}$ was conducted. Again, the MP-2a was chosen as the injection point, but this time at higher $\mathrm{Q}$ and WL than during TT-1. Instantaneous injection into IP-1 took place at 15:56. MP-4 (Onset HOBO U24-001I, $30 \mathrm{~min}$ sampling interval), the Veetõusme springs alternate position (MP-5) (Onset HOBO U24-001, 5 min sampling interval), one of the smaller intermittent springs of the WW group (MP-8a) (Onset HOBO U24-001, 5 min sampling interval) were chosen for the sampling points. The outflow from MP-4a was also equipped with an automatic data logger (Onset HOBO U24-001, 5 min sampling interval), however the device was likely buried in the stream sediments during installation and thus did not provide usable data.

As the Kihu borehole (MP-9) was already equipped with an automatic data logger (Onset HOBO U24-001, 30 min sampling interval) at the time of TT-4, its data could be used. Sampling continued until 22 November 2016 in MP-5 and MP-8a and until 1 December 2016 in MP-4 and MP-9. 


\section{RESULTS}

\section{SURFACE- AND GROUNDWATER MONITORING}

During the study period, three high water periods with multiple medium-to-high flood peaks were observed (Fig. 2). The first observed high water period took place from January to April $2015\left(\mathrm{MP}-1 \mathrm{Q}_{\max }=2.67 \mathrm{~m}^{3} / \mathrm{s}\right.$; $\mathrm{WL}_{\max }=58.77 \mathrm{~m}$ a.s.l.) and was initiated primarily by rainfall-induced snowmelt. The second high water period was observed from December 2015 to April 2016. In the first quarter of December 2015, an intense rain event (38.7 $\mathrm{mm}$ in four days) triggered a medium-high flood event $\left(\mathrm{MP}-1 \mathrm{Q}_{\max }=2.52 \mathrm{~m}^{3} / \mathrm{s}\right.$; $\mathrm{WL}_{\max }=58.72 \mathrm{~m}$ a.s.l.). The recession of the last peak was followed by another rainfall- and snowmelt-induced high flood event in February 2016, during which the MP-4 began to overflow and the highest WLs and Qs of the study period were measured $\left(\mathrm{MP}-1 \mathrm{Q}_{\max }=4.5 \mathrm{~m}^{3} / \mathrm{s} ; \mathrm{WL}_{\max }=59.39 \mathrm{~m}\right.$ a.s.l.). The third high water period $\left(\mathrm{MP}-1 \mathrm{Q}_{\max }=2.75 \mathrm{~m}^{3} / \mathrm{s} ; \mathrm{WL}_{\max }=58.81\right.$ $\mathrm{m}$ a.s.l.) was observed in November-December 2016. The lowest Q observed in MP-1 throughout the study period was $0.035 \mathrm{~m}^{3} / \mathrm{s}\left(\mathrm{WL}_{\min }=57.46 \mathrm{~m}\right.$ a.s.l.), while the average was $\mathrm{Q}=1.1 \mathrm{~m}^{3} / \mathrm{s}$.

Two incremental Q measurement campaigns with extra profiles in the recharge and discharge area of the karst system were carried out on 9 December 2015 and 12 February 2016 (see Figs. 1 \& 2). These measurements allowed water-loss rates in different parts of the recharge area to be estimated. The measurements proved that during the period of medium flow (9 December 2015; MP-1 $\mathrm{Q}=1.97 \mathrm{~m}^{3} / \mathrm{s}$; $\mathrm{WL}=58.50 \mathrm{~m}$ a.s.l.) up to $1.6 \mathrm{~m}^{3} / \mathrm{s}$ of water was lost in the stretch of river from MP-1 to the Virulase valley. About $0.3 \mathrm{~m}^{3} / \mathrm{s}$ was left to flow and sink in the numerous ponors of the Virulase valley. At that time, the summarised Q of the springs (MP-5 \& MP-6) in the discharge area was $1.38 \mathrm{~m}^{3} / \mathrm{s}$.

On 12 February 2016 the highest flow conditions of the period were observed. At that time $\sim 1.4 \mathrm{~m}^{3} / \mathrm{s}$ was lost in the stretch of river from MP-1 to MP-2a, while $0.26 \mathrm{~m}^{3} / \mathrm{s}$ bypassed the karst system by flowing along the Kuie dry valley. Summarised Q in the perennial spring group of Veetõusme (MP-5 and MP-6) was $2.24 \mathrm{~m}^{3} / \mathrm{s}$, while the Q of the intermittent stream flowing from the numerous intermittent springs of the WW group (including MP-4, MP-8, MP-8a and MP-4a) was $1 \mathrm{~m}^{3} / \mathrm{s}$.

In the case of medium-to-high flow conditions, the input Q (MP-1) was on average $0.4 \mathrm{~m}^{3} / \mathrm{s}$ higher than the output Q (MP-5 + MP-6 + MP-4) (Fig. 2). The output $\mathrm{Q}$ amounted to an average of $70-80 \%$ of the input Q. During periods of low flow, however, the corresponding relationship was reversed and the output could be nearly two times higher than the input $\mathrm{Q}$, as could be seen from October to November 2015 in Fig. 2.

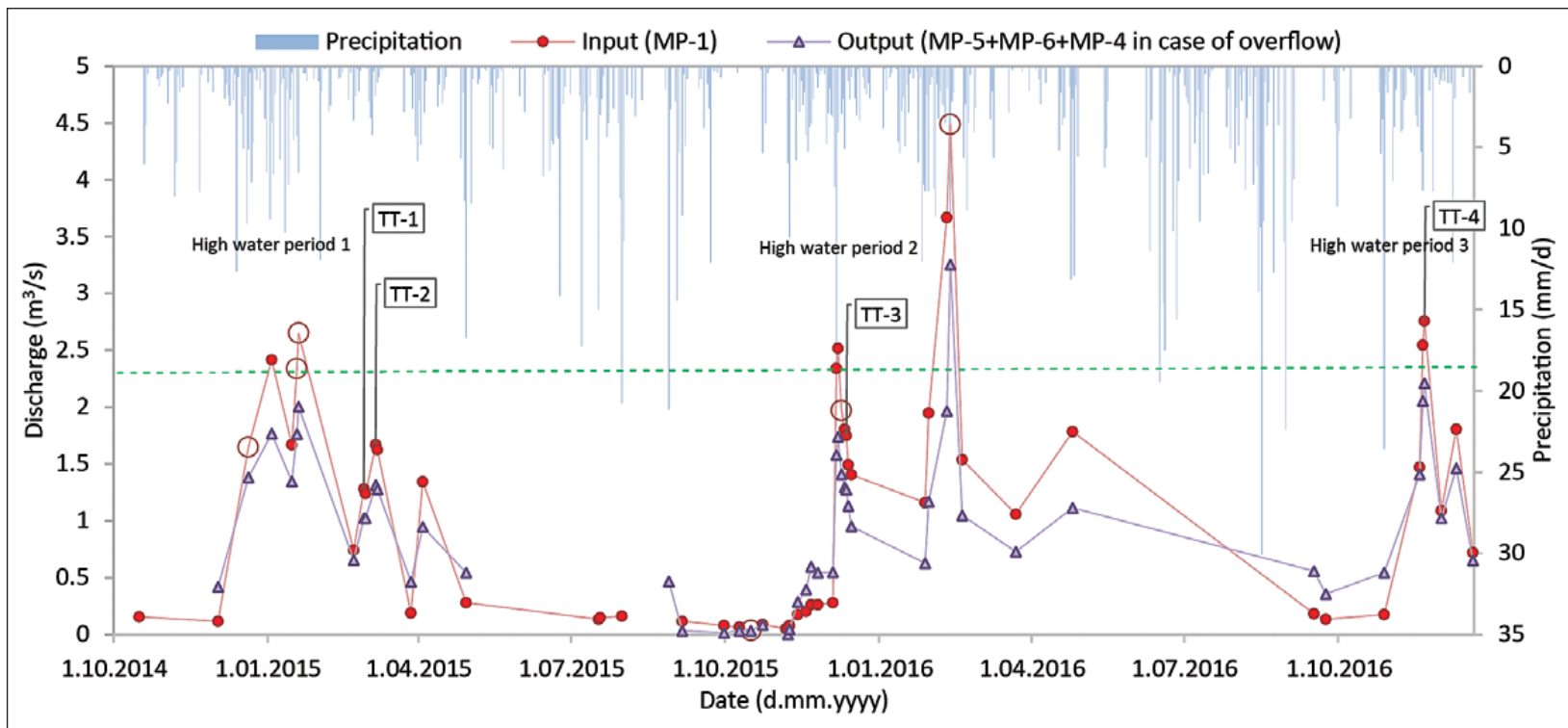

Fig. 2: The input-output $Q$ hydrograph of the TKA system for the study period. Three notable high water periods were observed. Output $Q$ comprises the summarised $Q$ s of MP-5, MP-6 and the $Q$ of the intermittent $W W$ group springs when active. During the peak flow of February $2016\left(M P-1 Q=4.5 \mathrm{~m}^{3} / \mathrm{s}\right), 0.26 \mathrm{~m}^{3} / \mathrm{s}$ bypassed the karst system through the Kuie dry valley, resulting in an actual system input $Q$ of $4.24 \mathrm{~m}^{3} / \mathrm{s}$. The dashed green line marks the approximate level of discharge above which the significant operation of the main springs in the WW group has been witnessed in the field. Data callouts mark the tracer tests carried out during the study period. The hollow red markers represent manually measured discharges. 
During the hourly WL and GWL monitoring of TT-3, the WLs of the discharge area (MP-4, MP-5 and MP-6) responded swiftly to the flow pulse caused by the lowering of the Kata dam (see the tracer test results chapter) in MP-1. Immediately after the dam was lowered the WL in MP-1 rose by about $6 \mathrm{~cm}$ between 10:45 and 11:54. By 12:00 it had risen $6 \mathrm{~cm}$ in MP-4 and, by 12:27-13:27, by about $1-1.5 \mathrm{~cm}$ in MP-5 and MP- 6 . After the attenuation of the pulse, all levels returned to former or slightly lower levels.

The short-time high-resolution GWL, EC and T series in MP-4 and MP-9 (only GWL) was logged for the period from 28 October to 1 December 2016 (Fig. 3) to characterise the response of MP- 4 and MP- 9 to a moderate recharge event. Between 1 and 15 November 2016, approximately $23.5 \mathrm{~mm}$ of snow fell. On 15 November, the air temperature rose above zero, and was followed by $22 \mathrm{~mm}$ of rainfall until 21 November, which triggered a snowmelt-induced medium-high flood event (MP-1 $\mathrm{WL}=58.81 \mathrm{~m}$ a.s.l.; $\mathrm{Q}=2.75 \mathrm{~m}^{3} / \mathrm{s}$ ). The graph shows the synchronous WL changes of MP-4 and MP-9. As the GWL reached $54.70 \mathrm{~m}$ a.s.l. (MP-1 $\mathrm{WL}=58.41 \mathrm{~m}$ a.s.l.; $\mathrm{Q}=1.75 \mathrm{~m}^{3} / \mathrm{s}$ ) in MP-4, a sharp decline in EC and T readings followed, indicating the arrival of event water and the connection of the WW to the system.

\section{TRACER TESTS}

Unusually high air temperature in January 2015 resulted in an early spring thaw. Due to the daily mean air T fluctuating around $0{ }^{\circ} \mathrm{C}$, the thin snow cover gradually melted away, triggering a moderate flood event. $\mathrm{NaCl}$ was injected into MP-2a at 15:10 and was detected in MP-6a
$2 \mathrm{~h} 23 \mathrm{~min}$ after the injection. The first peak of the breakthrough curve (BTC) formed within 40 minutes after the first detection, i.e. $3 \mathrm{~h} 03 \mathrm{~min}$ after the injection (TT-1, Fig. 4). Secondary peak was formed $4 \mathrm{~h} 15 \mathrm{~min}$ after the injection, and followed by low-amplitude EC fluctuations until the end of the sampling period. As the EC drops below the pre-monitoring levels, it could have been due to some operation interference of the monitoring device. The Q at MP-6a was constantly $1.02 \mathrm{~m}^{3} / \mathrm{s}$ throughout the sampling period. Only the recovered mass of tracer (R) for the two main peaks of the BTC could be calculated with confidence. Approximately $76 \%$ of the $300 \mathrm{~kg}$ of injected $\mathrm{NaCl}$ was recovered. The calculated linear flow velocities of karst groundwater during TT-1 are presented in Tab. 3. As the monitoring device in MP-4 malfunctioned, no usable data was obtained.

The slight rise of the WLs that had begun in the second half of February continued in early March. As the WLs were slightly higher (MP-1 WL=58.35 $\mathrm{m}$ a.s.l.; $\mathrm{Q}=1.63 \mathrm{~m}^{3} / \mathrm{s}$ ) than during TT-1, the river had established flow into one of the biggest ponors of the Virulase valley, namely the Virulase cave (MP-11), which provided suitable conditions for tracer injection. During the TT-2, the tracer injected at 13:50 was detected in MP- $6 \mathrm{~b} 1 \mathrm{~h} 41$ min after the injection (Fig. 4). The peak concentration was reached $28 \mathrm{~min}$ after the first detection, i.e. $2 \mathrm{~h} 09$ min after the injection. The Q at MP-6b was constantly $1.27 \mathrm{~m}^{3} / \mathrm{s}$ throughout the observation period. About $63 \%$ of the $200 \mathrm{~kg}$ of $\mathrm{NaCl}$ was recovered in MP- $6 \mathrm{~b}$ during the sampling period. The linear flow velocities of karst groundwater during TT-2 are presented in Tab. 3 . The tracer was not detected in MP-4.

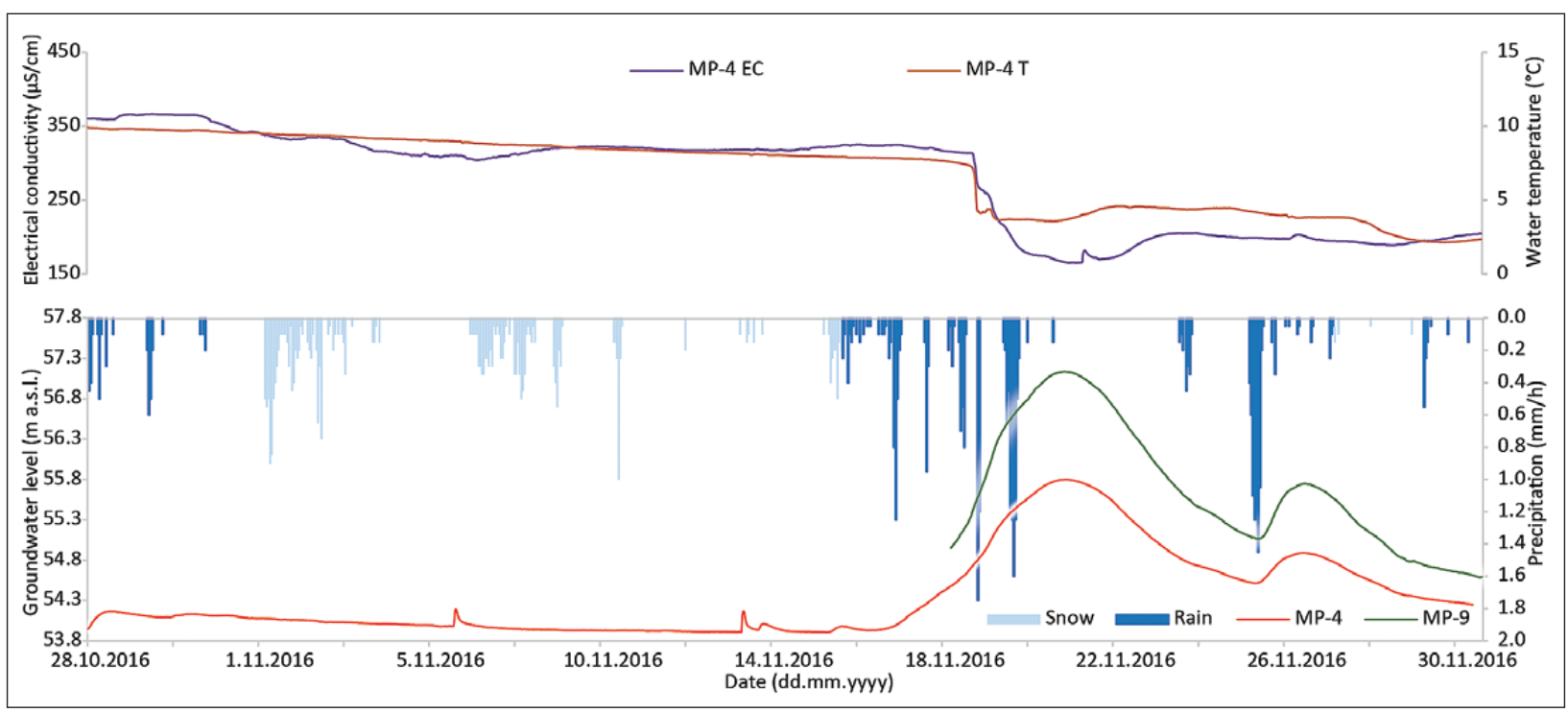

Fig. 3: Graph showing the behaviour of water EC and T following the GWL rise in MP-4 during the third observed high water period (November 2016) of the study period. For comparison, the GWL time series of MP-9 is included. 


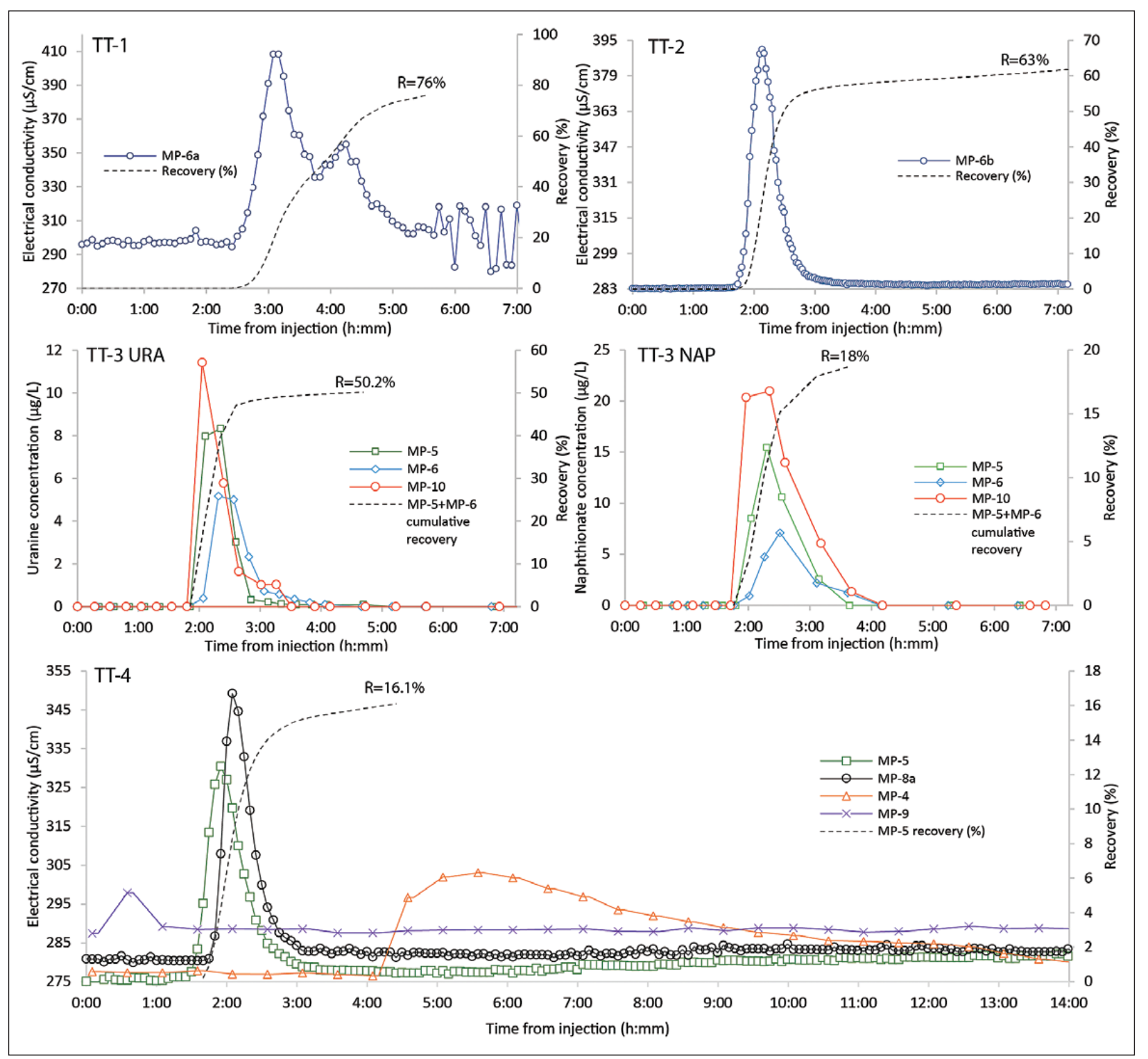

Fig. 4: Tracer breakthrough and recovered tracer mass curves of TT-1, TT-2, TT-3 and TT-4.

During the TT- 3 the URA which was injected into MP-2a at 10:44 was first detected in MP-10 $1 \mathrm{~h} 55 \mathrm{~min}$ after the injection, in MP-6 $1 \mathrm{~h} 56 \mathrm{~min}$ and in MP-5 $1 \mathrm{~h}$ 58 min after the injection (TT-3 URA, Fig. 4). Maximum URA concentrations were detected after $2 \mathrm{~h} 03 \mathrm{~min}$ in MP-10 reaching $11.4 \mu \mathrm{g} / \mathrm{L}$, after $2 \mathrm{~h} 21 \mathrm{~min}$ in MP-5 reaching $8.3 \mu \mathrm{g} / \mathrm{L}$ and after $2 \mathrm{~h} 19 \mathrm{~min}$ in MP-6 reaching $5.2 \mu \mathrm{g} / \mathrm{L}$. URA formed almost uniformly shaped, sharp BTCs in both MP-5 and MP- 6 . The summarised Q of MP-5 and MP-6 was approximately $1.28 \mathrm{~m}^{3} / \mathrm{s}\left(1.18 \mathrm{~m}^{3} / \mathrm{s}\right.$ in MP-5 and $0.097 \mathrm{~m}^{3} / \mathrm{s}$ in MP-6) and remained constant, except for $\sim 201 / \mathrm{s}$ fluctuations due to the pulse caused by the lowering of the dam at MP-1. This was taken into account when calculating the tracer recovery rate. About $50 \%$ of the $50 \mathrm{~g}$ of injected URA was recovered in MP-5
(47.5\%) and MP-6 (2.7 \%). The calculated linear flow velocities of karst groundwater according to URA are presented in Tab. 3.

The NAP injected into MP-12 at 12:17 was first detected in MP-10 $1 \mathrm{~h} 50 \mathrm{~min}$ after the injection, in MP-6 and MP-5 $1 \mathrm{~h} 53 \mathrm{~min}$ and $1 \mathrm{~h} 55 \mathrm{~min}$ after the injection, respectively (TT-3 NAP, Fig. 4). Maximum NAP concentrations were detected in MP-10 $2 \mathrm{~h} 21 \mathrm{~min}$ after the injection reaching $21.0 \mu \mathrm{g} / \mathrm{L}$, in MP-5 and MP-6 $2 \mathrm{~h} 16 \mathrm{~min}$ and $2 \mathrm{~h} 31 \mathrm{~min}$ after the injection, respectively. In MP-5 maximum concentration was $15.5 \mu \mathrm{g} / \mathrm{L}$ and in MP- 6 was $7.1 \mu \mathrm{g} / \mathrm{L}$. Both in MP-5 and MP-6 NAP formed almost uniformly shaped BTCs, which were slightly more dispersed than those of URA. Taking into account the almost constant summarised Q of $1.28 \mathrm{~m}^{3} / \mathrm{s}$, about $18 \%$ 
THRESHOLD-CONTROLLED THREE-STAGE HYDRAULIC BEHAVIOUR OF A MANTLED SHALLOW CARBONATE AQUIFER ...

Tab. 3: Hydrodynamic parameters of karst groundwater based on the results of TT-1, TT-2, TT-3 and TT-4.

\begin{tabular}{|c|c|c|c|c|c|c|c|c|c|c|c|c|c|}
\hline $\begin{array}{c}\text { Tracer } \\
\text { test }\end{array}$ & $\begin{array}{c}\text { Injection } \\
\text { point }\end{array}$ & $\begin{array}{c}\text { Injection } \\
\text { time } \\
\text { (hh:mm) }\end{array}$ & $\begin{array}{c}\text { Detection } \\
\text { point }\end{array}$ & \begin{tabular}{|} 
Linear \\
distance \\
(m)
\end{tabular} & $\begin{array}{c}\text { Hydraulic } \\
\text { gradient }\end{array}$ & $\begin{array}{l}\text { Time of first } \\
\text { detection } \\
\text { (h:mm) }\end{array}$ & $\begin{array}{c}\text { Linear } \\
\text { maximum } \\
\text { flow velocity } \\
(\mathrm{m} / \mathrm{h})\end{array}$ & $\begin{array}{c}\text { Peak } \\
\text { transit } \\
\text { time } \\
\text { (h:mm) }\end{array}$ & $\begin{array}{c}\text { Linear } \\
\text { dominant } \\
\text { flow velocity } \\
(\mathrm{m} / \mathrm{h})\end{array}$ & $\begin{array}{c}\text { Time of } \\
\text { half- } \\
\text { recovery } \\
\text { (h:mm) }\end{array}$ & $\begin{array}{c}\text { Mean } \\
\text { flow } \\
\text { velocity } \\
(\mathrm{m} / \mathrm{h})\end{array}$ & $\begin{array}{c}\text { Qin } \\
\text { detection } \\
\text { point } \\
\left(\mathrm{m}^{3} / \mathrm{s}\right)\end{array}$ & $\begin{array}{c}\text { Recovery } \\
\text { (\%) }\end{array}$ \\
\hline TT-1 & MP-2a & $15: 10$ & MP-6a & 1252 & 0.0033 & $2: 23$ & 525 & $3: 03$ & 410 & $3: 23$ & 370 & 1.02 & 76 \\
\hline TT-2 & MP-11 & $13: 50$ & MP-6b & 1042 & 0.0026 & $1: 41$ & 619 & $2: 09$ & 485 & $2: 13$ & 470 & 1.27 & 63 \\
\hline \multirow{6}{*}{ TT-3 } & MP-2a & $10: 44$ & MP-10 & 1144 & 0.0032 & $1: 55$ & 597 & $2: 03$ & 558 & NA & NA & NA & NA \\
\hline & MP-2a & $10: 44$ & MP-6 & 1238 & 0.0032 & $1: 56$ & 640 & $2: 19$ & 534 & $2: 32$ & 489 & 0.097 & 2.7 \\
\hline & MP-2a & $10: 44$ & MP-5 & 1214 & 0.0034 & $1: 58$ & 617 & $2: 21$ & 517 & $2: 14$ & 544 & 1.18 & 47.5 \\
\hline & MP-12 & $12: 17$ & MP-10 & 898 & 0.0025 & $1: 50$ & 490 & $2: 21$ & 382 & NA & NA & NA & NA \\
\hline & MP-12 & $12: 17$ & MP-6 & 996 & 0.0027 & $1: 53$ & 529 & 2:31 & 396 & $2: 23$ & 418 & 0.097 & 0.72 \\
\hline & MP-12 & $12: 17$ & MP-5 & 964 & 0.0029 & $1: 55$ & 503 & $2: 16$ & 425 & $2: 16$ & 425 & 1.18 & 17.3 \\
\hline \multirow{4}{*}{ TT-4 } & MP-2a & $15: 56$ & MP-9 & 113 & 0.015 & $0: 30(\max )^{*}$ & 226 & $0: 30^{*}$ & 226 & NA & NA & NA & NA \\
\hline & MP-2a & $15: 56$ & MP-5 & 1214 & 0.0036 & $1: 31$ & 800 & $1: 56$ & 628 & $2: 00$ & 607 & 2 & 16.1 \\
\hline & MP-2a & $15: 56$ & MP-8a & 1070 & 0.0033 & $1: 51$ & 578 & $2: 06$ & 510 & NA & NA & NA & NA \\
\hline & MP-2a & $15: 56$ & MP-4 & 1036 & 0.0028 & $4: 36$ & 225 & $5: 36$ & 185 & NA & NA & NA & NA \\
\hline
\end{tabular}

NA - not applicable

* Probable aliasing effect due to low sampling frequency

of $250 \mathrm{~g}$ of the injected NAP was recovered at MP-5 $(17.3 \%)$ and at MP-6 (0.72\%). The calculated linear flow velocities are presented in Tab. 3 . Tracers were not detected in the other sampling points.

During the TT-4 the $\mathrm{NaCl}$ was injected into MP-2a at 15:56 and first detected half an hour later in borehole MP-9 situated 113 m NE of MP-2a (Figs. 1 and 4). However, a very probable aliasing effect caused by a too low sampling frequency may have blurred the tracer first detection and peak concentration. In MP-5, the tracer was first detected $1 \mathrm{~h} 31 \mathrm{~min}$ after the injection and the peak concentration was reached $1 \mathrm{~h} 56 \mathrm{~min}$ after the injection.
MP-5 was the only sampling point where Q $\left(2 \mathrm{~m}^{3} / \mathrm{s}\right)$ and consequently the tracer recovery could be estimated. Approximately $16.1 \%$ of the $200 \mathrm{~kg}$ of the injected $\mathrm{NaCl}$ was recovered. In MP-8a the tracer was detected $1 \mathrm{~h} 51$ min after the injection and the peak concentration was reached $2 \mathrm{~h} 06 \mathrm{~min}$ after the injection. Tracer was detected much later in MP-4 (4 h 36 min after the injection) than in the nearby MP-8a. The BTC in MP-4 was more dispersed in comparison to the other BTCs. The peak concentration in MP-4 was reached 5 h 36 min after the injection. The calculated linear flow velocities of karst groundwater are presented in Tab. 3 .

\section{THE CONCEPTUAL MODEL}

\section{BASIC CONSIDERATION}

The TKA system exhibits the variable hydrogeological properties of the recharge and discharge areas. The performed field observations and hydrometrical measurements permitted their detailed identification and characterisation. In addition, physico-chemical monitoring, water balance calculations and four tracer tests performed in different hydrological conditions showed that the observed shallow karst system is characterised by well-developed conduit-type flow allowing rapid groundwater travel velocities.

The karst system is primarily recharged by the allogenic Tuhala River. However, a portion of the recharge possibly originates from the adjacent shallow carbonate aquifer or from the surface directly above the system. Depending on the hydrological conditions, the river sinks in the stretch between the grike zone of Ämmaauk (MP-2, MP-2a and MP-3) and the numerous ponors in the Virulase valley (MP-11 and MP-12). The recharge area mainly drains towards the Veetõusme spring group (MP-5 \& MP-6). During medium hydrological conditions, the groundwater linear maximum flow velocities between the recharge and discharge area mostly range between $\sim 500$ and $640 \mathrm{~m} / \mathrm{h}$, despite the relatively low hydraulic gradient (0.0027-0.0034) (Tab. 3).

Although the hydraulic connection between the WW group (MP-4, MP-4a, MP-8 and MP-8a) and the rest of the karst system had been detected during medium flow conditions, as evidenced during the hourly WL/ GWL monitoring of TT-3 and the short time series of MP-4/MP-9, not all tracer tests proved this connection. A direct flow connection between the recharge area and 


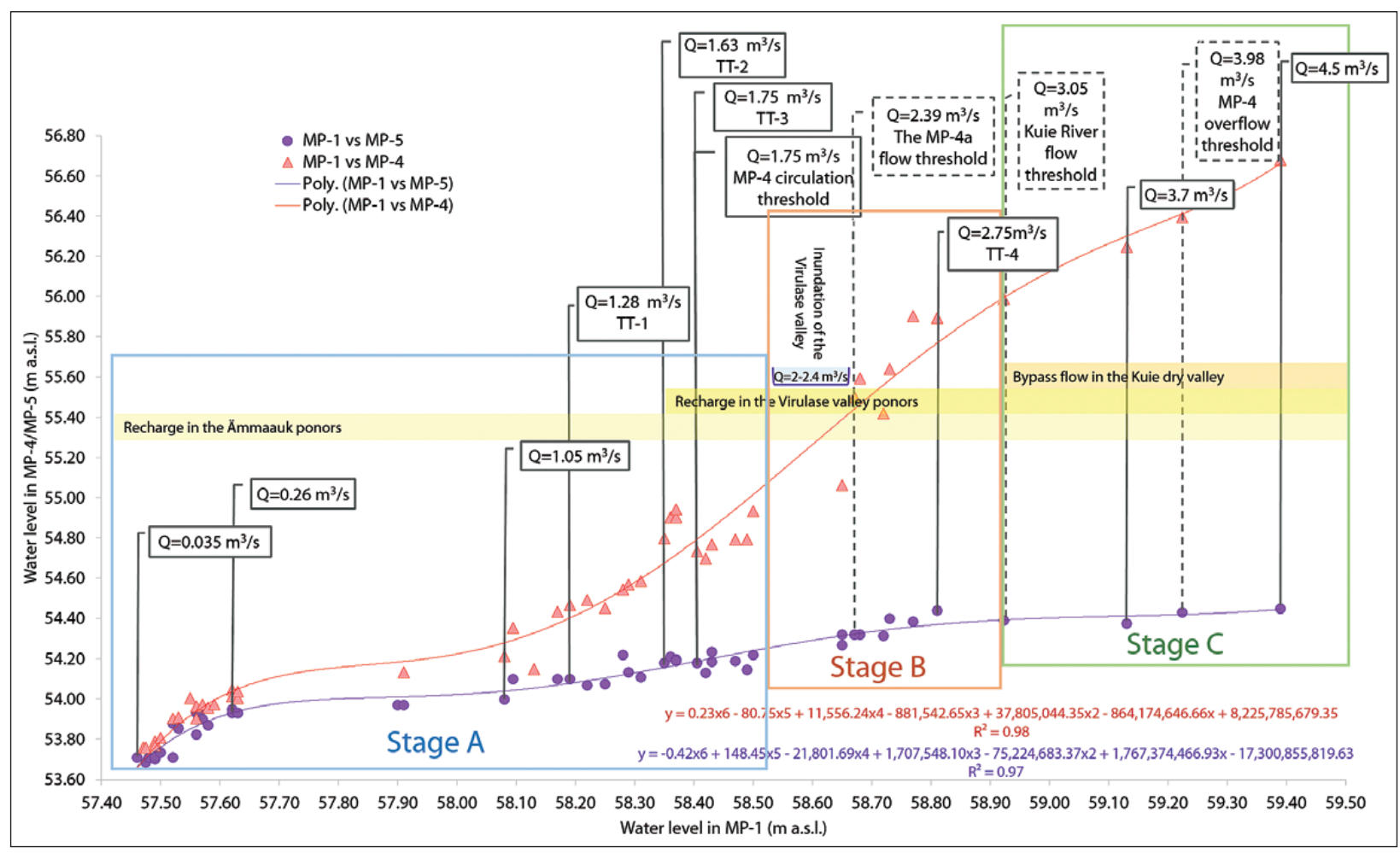

Fig. 5: WL/GWL relation curves for MP-1 vs MP-4 and MP-1 vs MP-5. Solid line callouts represent observed events. Dashed line callouts represent interpolated events.

the WW group (MP-4 \& MP-8a) was only proven during medium-high to high flow conditions. Then, the flow velocities towards the Veetõusme spring group reached about $800 \mathrm{~m} / \mathrm{h}$. At the same time, the flow velocities in the WW spring group reached $578 \mathrm{~m} / \mathrm{h}$ in MP-8a and only $225 \mathrm{~m} / \mathrm{h}$ in MP-4, despite a gradient of the same order of magnitude, respectively of 0,33 and 0,28 (Tab. 3). As MP-4 is presumably located on top of a bounded conduit, as also evidenced by the analogous MP-4a, the possible explanation for such damped tracer breakthrough in MP-4 could have been because of obstructed through flow/limited circulation caused by the semi-closed environment of the WW. The latter is also the reason for the pressurized outflow of the spring water at the WW. The retrieved tracer tests data at the Veetõusme springs show uniformly shaped BTCs, indicating the transfer of tracers through well-permeable karst channels. The MP-4 BTC was, by comparison, more elongated, indicating probable restrictions and/or temporary storage within the system (Benischke et al. 2007).

\section{SYSTEM THRESHOLDS}

In order to reveal the hydrodynamic thresholds and functioning of the system, an input-output WL/GWL relation curve has been established for MP-1, MP-4 and MP-5 (Fig. 5). In both cases (MP-1 vs MP-4 and
MP-1 vs MP-5), a positive non-linear relationship, inherent to karst systems worldwide (Zehe \& Sivapalan 2009; Birk et al. 2014; Chinarro 2014), is evident. The strength of the relationship indicates a direct hydraulic link between the WLs and GWLs of the recharge and discharge area. The data points were best fitted by sixth-order polynomial curves. Based on the shapes of the relation curves, three partly overlapping but distinguishable stages (A, B and C) caused by the shifts in the WL/GWL balance could be delineated. The shifts occur synchronously in both curves but are more acute in the case of MP-1 vs MP-4, as the latter characterises the piezometric GWL in a well. These shifts could be interpreted as changes in the hydraulic behaviour of the karst system (Maidment 1993; Braca 2008) controlled by a number of thresholds.

Based on the descriptive power of the relation curves, the threshold conditions of some unmeasured hydrological events could be interpolated. As WLs were measured immediately before and during the MP-4 overflow event on 12 February 2016, the approximate threshold preconditions in the recharge area (MP-1 $\mathrm{Q}=3.98 \mathrm{~m}^{3} / \mathrm{s} ; \mathrm{WL}=59.22 \mathrm{~m}$ a.s.l.) could be interpolated. The prerequisite conditions in MP- 1 for the Kuie dry valley flow threshold WL (MP-1 Q=3.05 m³ $/ \mathrm{s}$; WL=58.92 $\mathrm{m}$ a.s.l.) was interpolated from the measured $\mathrm{WL}$ data of 
MP-1, MP-2, MP-3 and two single measurements taken in front of the MP-11. To better understand the regime shifts, the observed and interpolated events were marked in the curves.

The imbalance between the input and output Qs of the TKA system presented in Fig. 2 is due to several factors participating in the formation of the water budget (Stevanović 2015). In the absence of detailed data on the proportion of groundwater inflow/outflow and possible storage, there are several options causing the imbalance.

To some extent, the imbalance could be attributed to the threshold-controlled dynamic throughput capacity of the karst system. First, the increase in input WLs and Qs brings increase in the hydraulic gradient, pressure and flow velocities, thereby allowing more water to flow through the karst system. In addition, the increase in WL/GWL could possibly allow the water in the recharge area to flow through higher positioned conduits. This has been confirmed by field observations, according to which the Virulase valley was to become inundated with Qs exceeding the approximate $2-2.4 \mathrm{~m}^{3} / \mathrm{s}$ flow threshold in MP-1, coinciding with the change between the $\mathrm{B}$ and $\mathrm{C}$ stages of the relation curves. The change between the $\mathrm{B}$ and $\mathrm{C}$ stages is caused due to the WL/GWL balance relationship of the karst system gradually shifting towards the recharge area, bringing more intensive WL increases in MP-1 compared to MP-5. The regime shift in MP-4 is more obscure as it is a semi-closed environment, most likely caused by the input $\mathrm{Q}$ reaching the throughput capacity of the karst system. During periods of low flow, it is evident that base flow originating from the adjacent shallow aquifer (as yet unidentified) forms the majority of the output in the discharge area.

When assessing the GWL and EC time-series of MP-4 (Fig. 3), it was evident that during medium flow conditions MP-4 is hydraulically linked to the karst system, since the GWL responded swiftly to fluctuations in MP-9 (a drilled well in the recharge area that was proved (TT-4) to be directly connected to the river during medium-high flows). As the GWL in MP-4 began to rise simultaneously with the WL/GWL levels in the recharge area on 17 November 2016, it was first accompanied by a gradual decrease in EC and T. As the GWL in MP-4 reached the $54.70 \mathrm{~m}$ a.s.l. mark (MP-1 $\mathrm{Q}=1.75 \mathrm{~m}^{3} / \mathrm{s}$; $\mathrm{WL}=58.42 \mathrm{~m}$ a.s.l.), the EC and $\mathrm{T}$ dropped abruptly owing to the sudden arrival of fresh water from the recharge area. This refers to another so-called flow threshold that had to be overcome in order to allow active circulation in the formerly static WW group conduits. This event could also be related to the flow connection establishment in the ponor zone of the Virulase valley at $\mathrm{Q}=1.63-1.75 \mathrm{~m}^{3} / \mathrm{s}$ in $\mathrm{MP}-1$.
Since the whole TKA is confined by a layer of poorly permeable glacial till and the WW spring group is situated in a shallow depression in Quaternary cover, it was observed that MP-4a (as one of the biggest springs in the group) and other intermittent springs in the WW group would activate when the specific threshold GWL was exceeded in MP-4. As the elevation of the outflow threshold from the MP-4a was derived from the field $(55.5 \mathrm{~m}$ a.s.l.) it was possible to interpolate the prerequisite conditions in $\mathrm{MP}-1\left(\mathrm{Q}=2.39 \mathrm{~m}^{3} / \mathrm{s} ; \mathrm{WL}=58.67 \mathrm{~m}\right.$ a.s.l. $)$. The interpolated flow threshold, when plotted on the WL/ GWL relation curve, would fall in the B stage (Fig. 5), further confirming that it is an important turning point in the hydraulic behaviour of the karst system.

A hypothesis was proposed that the $55.5 \mathrm{~m}$ a.s.l. GWL threshold discussed above had to be exceeded in MP-4 and MP-4a for substantial tracer detection in the WW group. TT-4, carried out during medium-high flow conditions (MP-1 Q $=2.75 \mathrm{~m}^{3} / \mathrm{s} ; \mathrm{WL}=58.81 \mathrm{~m}$ a.s.l.), proved the hypothesis of the proposed GWL threshold of the WW group, since tracers were detected in MP-4 and MP-8a as well as in the Veetõusme group (MP-5). Such threshold-controlled functioning is typical of dammed or overflow karst springs, as also described by Smart (1983) and Ford \& Williams (2007). However, the anomalously long time until first detection in MP-4 compared to detection in MP-8a raises questions and remains a subject for future studies. Although direct comparison of the recovery of different tracers has certain limitations (i.e. due to different intrinsic properties of tracers, analytical detection limits), the considerably lower recovery of $\mathrm{NaCl}$ in MP-5 (16.1\%) during TT-4 compared to the recovery of URA during TT-3 (47.5\%) indicates a shift in groundwater flow distribution. It can be deduced that after a specific flow threshold is overcome in the system, a significant portion of the water that recharged the preferential flow path to the Veetõusme group during lowto-medium conditions is diverged to the $\mathrm{WW}$ group.

\section{CONCEPTUAL MODEL SET-UP}

Based on the information obtained and inferences derived, the three stages ( $\mathrm{A}, \mathrm{B}$ and $\mathrm{C})$ distinguished in the hydraulic behaviour of the TKA system were compiled in a conceptual model.

Stage A (Fig. 6) represents the karst system during low (baseflow) to medium flow conditions (MP-1 $\mathrm{Q}=0.035-2 \mathrm{~m}^{3} / \mathrm{s}$ ). During stage A, the Tuhala River sinks primarily in the Ämmaauk ponor zone. Its ponor capacity is estimated to be around $1.65 \mathrm{~m}^{3} / \mathrm{s}$ (Koit 2016). The water mainly flows towards the Veetõusme spring group. During low flow conditions, a greater proportion of the Q of the Veetõusme springs could be attributed to autogenic recharge from the adjacent aquifer. In the later 


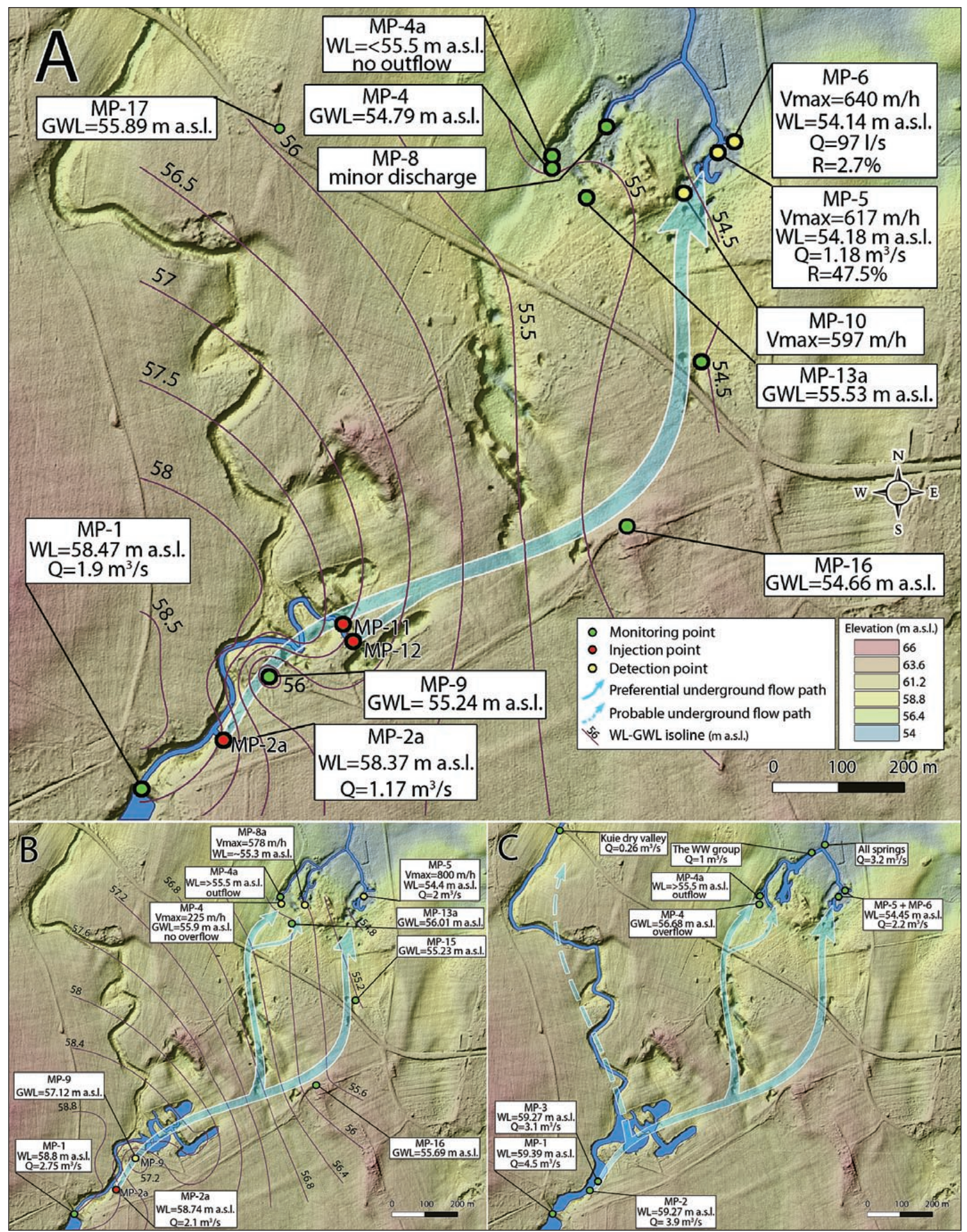

Fig. 6: The conceptual models representing the hydraulic behaviour of the karst system during the proposed A, B and C stages. Stage A is based on the hydrological conditions observed on 12 December 2015 ( $M P-1 \mathrm{WL}=58.47 \mathrm{~m}$ a.s.l.; $\left.Q=1.9 \mathrm{~m}^{3} / \mathrm{s}\right)$ and 10 December 2016 and the results of TT-1, TT-2 and TT-3. Stage B is based on the hydrological conditions observed on 21 November $2016\left(M P-1 W L=58.81 \mathrm{~m}\right.$ a.s.l.; $\left.Q=2.75 \mathrm{~m}^{3} / \mathrm{s}\right)$ and the results of TT-4. Stage $C$ is based on the hydrological conditions observed on 12 February 2016 (MP-1 WL=59.39 $\mathrm{m}$ a.s.l.; $\left.Q=4.5 \mathrm{~m}^{3} / \mathrm{s}\right)$. The preferential underground flow paths were estimated on the basis of the results of the tracer tests, WL-GWL isolines and major surface features. The probable underground flow path of the Kuie dry valley during stage C was interpreted on the basis of Heinsalu (1978) and Sooäar (1980). Raw LIDAR data (resolution $5 \times 5 \mathrm{~m}$ ) was provided by the Estonian Land Board. 
phase of stage A, as WL rises, the flow to the Virulase valley ponor zone is established. This probably leads to the gradual activation (circulation threshold in MP-4) of the secondary flow path to the WW group in stage B. In addition, it is evident that the aquifer's behaviour is not linear throughout the stage A as appears in Fig. 5. The aquifers behavior during low Qs should further be studied in detail when additional data is aquired.

Stage B represents the karst system during medium to medium-high flow conditions (MP-1 $\mathrm{Q}=2-3 \mathrm{~m}^{3} / \mathrm{s}$ ). The stage is characterised by a gradual activation of the WW spring group. When the Q in MP-1 reaches $2-2.4 \mathrm{~m}^{3} / \mathrm{s}$, the first threshold of dynamic throughput capacity of the karst system is met and the Virulase valley is gradually inundated.
The total ponor capacity of the Ämmaauk and Virulase ponor zones could be estimated to about $3 \mathrm{~m}^{3} / \mathrm{s}$, followed by the establishment of surface flow in the Kuie dry valley. The latter could be the event to lead the karst system into the stage $\mathrm{C}$. As the WL/GWLs continue to rise, the overflow of the WW (MP-4) is established at $\mathrm{Q}=3.98 \mathrm{~m}^{3} / \mathrm{s} ; \mathrm{WL}=59.22 \mathrm{~m}$ a.s.l. in MP-1. Current estimates of the maximum throughput capacity of the karst system are based on the study period's maximum conditions observed the 12 February 2016. There is evidence (Koit 2016) that the Q of the Tuhala River has reached $10 \mathrm{~m}^{3} / \mathrm{s}$ in the past, which indicates that the behaviour of the karst system during extreme conditions has yet to be studied and specified.

\section{CONCLUSIONS}

The ascertaining and reconciliation of some of the system's key threshold values coupled with input-output WL/GWL relation curve analysis proved to be effective in achieving a better understanding of the non-linear functioning of a karst system. The threshold values predicted or obtained on the basis of data from surface and groundwater hydrometrical/physico-chemical monitoring, field observations and tracer tests were put into the context of the developed water level relation curves. The proposed threshold values allowed us to delineate the relation curves into distinct parts representing the various stages of the hydraulic regime of the Tuhala karst system.

The outcome of the combined approach revealed that the Tuhala karst system features well-developed conduit-type porosity with rapid flow velocities (up to $\sim 800 \mathrm{~m} / \mathrm{h}$ ). Although the karst system mainly recharges from the allogenic Tuhala River, interaction with the adjacent shallow aquifer is perceptible when assessing input and output Qs. "The latter needs further research". During the period October 2014-December 2016, the hydraulic behaviour of the Tuhala karst system could be broadly divided into three stages. The proposed stage A represents the karst system during low to medium flow conditions (MP-1 $\mathrm{Q}=0.035-2 \mathrm{~m}^{3} / \mathrm{s}$ ). During this stage, the increase in input $\mathrm{Q}$ in the recharge area is accompanied by the gradual expansion of the active sinking zone towards the Virulase valley. Throughout stage A the karst system is primarily drained by the Veetõusme perennial spring group. The proposed stage B represents the karst system during medium to medium-high flow conditions (MP-1 $\mathrm{Q}=2-3 \mathrm{~m}^{3} / \mathrm{s}$ ), while the inundation of the Virulase valley is accompanied by the gradual activation of the Witch's Well intermittent spring group. After the dynamic throughput capacity of the system is met in the recharge area, surface flow along the Kuie dry valley is established, leading the system into the proposed stage C. In this stage, the continuing rise of WL/GWLs results in the overflow of the Witch's Well (MP-4) when Q=3.98 $\mathrm{m}^{3} / \mathrm{s}$ and $\mathrm{WL}=59.22 \mathrm{~m}$ a.s.l. are achieved in the recharge area.

The developed conceptual understanding and numerical basis of the hydrological functioning of a selected karst aquifer can serve as foundation for further studies, such as assessment of contaminant transport and prediction of other negative impacts on the groundwater regime (e.g. over-pumping, climate change). Likewise, the results bring new insights and better understanding of the surface-groundwater interaction in karst aquifers. This article also features one of the first international study on Estonian karst. The knowledge obtained could be transferable to other conduit-dominated carbonate systems characterised by variability of flow dynamics in response to different hydrological conditions, such as the Dinaric karst, lowland karst areas of Ireland, the coastal karst of the Yucatan peninsula, subtropical areas of South China karst and others. 


\section{ACKNOWLEDGEMENTS}

This research was supported by the institutional research grant of the School of Natural and Health Sciences of Tallinn University, the research grant of Tallinn University and the Institute of Ecology at Tallinn University. The authors would like to thank the two anonymous review- ers for comprehensive feedback, Aksel Erit, Ants Talioja, Argo Kuusik, Rein Perens, Jan Erik Sintonen, Karl Peet, Margit Kaldmäe, Joonas Pärn, Reimo Rivis, Marko Vainu, Tanel Vahter, Tiiu Koff and the kind people of the Kata village.

\section{REFERENCES}

Bakalowicz, M., 2005: Karst groundwater: a challenge for new resources.- Hydrogeology Journal, 13, 148160. DOI:10.1007/s10040-004-0402-9.

Benischke, R., Goldscheider, N. \& C. Smart, 2007: Tracer techniques.- In: Goldscheider, N. \& D. Drew, (eds.) Methods in Karst Hydrogeology. Taylor \& Francis, pp. 147-170, London.

Birk, S., Wagner, T. \& C. Mayaud, 2014: Threshold behavior of karst aquifers: the example of the Lurbach karst system (Austria).- Environmental Earth Sciences, 72, 5, 1349-1356. DOI:10.1007/s12665-014 -3122-z.

Bonacci, O. \& I. Andrić, 2015: Karst spring catchment: an example from Dinaric karst. Environmental Earth Sciences, 74, 7, 6211-6223. DOI:10.1007/ s12665-015-4644-8.

Bonacci, O., 1987: Karst hydrology with special references to the Dinaric karst.- Springer, pp. 184, Berlin.

Braca, G., 2008: Stage-discharge relationships in open channels: Practices and problems.- Dipartimento di Ingegneria Civile e Ambientale, Università degli Studi di Trento, pp. 28, Trento.

Calligaris, C., Boschin, W., Cucchi, F. \& L. Zini, 2016: The karst hydrostructure of the Verzegnis group (NE Italy).- Carbonates and Evaporites, 31, 4, 407-420. DOI: 10.1007/s13146-016-0320-7.

Chinarro, D., 2014: System Engineering Applied to Fuenmayor Karst Aquifer (San Julián de Banzo, Huesca) and Collins Glacier (King George Island, Antarctica).- PhD thesis. University of Zaragoza, pp. 159. DOI:10.1007/978-3-319-08858-7.

Davis, K. W. \& L. D. Putnam, 2013: Conceptual and numerical models of groundwater flow in the Ogallala aquifer in Gregory and Tripp Counties, South Dakota, water years 1985-2009. U.S. Geological Survey Scientific Investigations Report 2013-5069.- U.S. Geological Survey, Reston, Virginia U.S. Geological Survey, pp. 82, Reston.
Fiorillo, F., Esposito, L. \& F. M. Guadagno, 2007: Analyses and forecast of water resources in an ultra-centenarian spring discharge series from Serino (Southern Italy).- Journal of Hydrology, 336, 1, 125-138. DOI:10.1016/j.jhydrol.2006.12.016.

Ford, D. C. \& P. W. Williams, 2007: Karst Hydrologeology and Geomorfology.- John Wiley \& Sons Ltd, pp. 562, Chichester.

Gabrovšek, F., Kogovšek, J., Kovačič, G., Petrič, M., Ravbar, N. \& J. Turk, 2010: Recent results of tracer tests in the catchment of the Unica River (SW Slovenia).- Acta carsologica, 39, 1, 27-37. DOI:10.3986/ ac.v39i1.110.

Gill, L. W., Naughton, O. \& P. M. Johnston, 2013: Modeling a network of turloughs in lowland karst.Water Resources Research, 49, 6, 3487-3503. DOI:10.1002/wrcr.20299

Goldscheider, N., Drew, D. \& S. Worthington, 2007: Introduction.- In: Goldscheider, N. \& D. Drew, (eds.) Methods in Karst Hydrogeology. Taylor \& Francis, pp. 1-8, London.

Heinsalu, Ü., 1978: Karst ja karstiveed maa-aluste jõgede ja allikate aladel Põhja-Eestis ja nende kaitse.- ENSV Teaduste Akadeemia Geoloogia Instituut, Tallinn.

Heinsalu, Ü., 1977: Karst ja looduskeskond Eesti NSV-s.Valgus, pp. 96, Tallinn.

Herczeg, A. L., Leaney, F. W. J., Stadler, M. F., Allan, G. L. \& L. K. Fifield, 1997: Chemical and isotopic indicators of point-source recharge to a karst aquifer, South Australia.- Journal of Hydrology, 192, 1-4, 271-299. DOI:10.1016/S0022-1694(96)03100-9.

Herman, E. K., Toran, L. \& W. B. White, 2008: Threshold events in spring discharge: Evidence from sediment and continuous water level measurement.Journal of Hydrology, 351, 98-106. DOI:10.1016/j. jhydrol.2007.12.001. 
Karro, E., Marandi, A., Vaikmäe, R. \& M. Uppin, 2009: Chemical peculiarities of the Silurian-Ordovician and Cambrian-Vendian aquifer systems in Estonia: an overview of hydrochemical studies.- Estonian Journal of Earth Sciences, 58, 4, 342-352. DOI:10.3176/earth.2009.4.12.

Karst ja allikad Pandiveres, 2002. AS Maves, pp. 52, Tallinn.

Kink, H., 2007: Keskkonna-uuringud Nabala lubjakivimaardla piirkonnas. MTÜ Pakri Looduskeskus, pp. 23, Tallinn.

Koit, O., 2016: Hydrogeological and hydrogeological study of Tuhala karst area.- MSc thesis. School of Natural Sciences and Health, Tallinn University, pp. 92.

Kogovšek, J. \& H. Liu, 2011: Characteristics of the underground water flow in the Tianshengan area at high water level.- In: Knez, M., Liu, H. \& T. Slabe, (Eds.) South China Karst II. ZRC Publishing, pp. 183-191, Ljubljana.

Kottek, M., Grieser, J., Beck, C., Rudolf, B. \& F. Rubel, 2006: World Map of the Köppen-Geiger climate classification updated.- Meteorologische Zeitschrift, 15, 259-263. http://dx.doi.org/10.1127/0941-2948 /2006/0130.

Kulakowski, Z. P., 2010: Chromophoric dissolved organic carbon loading of five intermittent streams recharging Wakulla springs, Florida.- MSc thesis. College Of Arts And Sciences, The Florida State University, pp. 169.

Laas, L. \& I. Jürine, 1974: Harju rajooni "Sotsialismi Tee" kolhoosi Kata maaparandusehitis. Hüdrogeoloogiline aruanne.- Tallinn.

Maastik, A. 1973: Kata karstiala.- Diploma thesis. University of Tartu, Department of Physical Geography, Tartu.

Maidment, D. R., 1993: Handbook of Hydrology.McGraw-Hill, pp. 1424, New York.

Mayaud, C., Wagner, T., Benischke, R. \& S. Birk, 2014: Single event time series analysis in a binary karst catchment evaluated using a groundwater model (Lurbach system, Austria).- Journal of Hydrology, 511, 628-639. DOI:10.1016/j.jhydrol.2014.02.024.

McCormack, T., Naughton, O., Johnston, P. M. \& L. W. Gill, 2016: Quantifying the influence of surface water-groundwater interaction on nutrient flux in a lowland karst catchment.- Hydrology and Earth System Sciences, 20, 2119-2133. DOI:10.5194/ hess-20-2119-2016.

Meng, X., Yin, M., Ning, L., Liu, D. \& X. Xue, 2015: A threshold artificial neural network model for improving runoff prediction in a karst watershed.Environmental Earth Sciences, 74, 6, 5039-5048. DOI:10.1007/s12665-015-4562-9.
Mudarra, M. \& B. Andreo, 2011: Relative importance of the saturated and the unsaturated zones in the hydrogeological functioning of karst aquifers. The case of Alta Cadena (Southern Spain).- Journal of Hydrology, 397, 3-4, 263-280. DOI:10.1016/j. jhydrol.2010.12.005.

Naughton, O., Johnston, P. M. \& L. W. Gill, 2012: Groundwater flooding in Irish karst: The hydrological characterisation of ephemeral lakes (turloughs).Journal of Hydrology, 470, 82-97. DOI:10.1016/j. jhydrol.2012.08.012.

Olesk, K., 2016: 2015. Aasta põhjaveevaru bilanss.- Data Management Department, Estonian Environment Agency, pp. 55, Tallinn.

Onset, 2017: Onset HOBO and InTemp Data Loggers.[Online] Available from: http://www.onsetcomp. com/ [Accessed 26th July 2017].

Perens, R., 1998: Eesti hüdrogeoloogiline kaart mõotkavas 1:400 000.- Eesti Geoloogiakeskus, pp. 40, Tallinn.

Perens, R. \& L. Vallner, 1997: Water-bearing formation.In: Raukas, A. \& A. Teedumäe (eds) Geology and Mineral Resources of Estonia. Estonian Academy Publishers, pp. 137-145, Tallinn.

Petersell, V., Ramst, R., Savitski, L., Lehtmets, K., Truu, M., Täht-Kok, K., Shtokalenko, M. \& E. Põldvere, 2011: Nabala lubjakivimaardla Nõmmevälja karjääri rajamise ja lubjakivi kaevandamisega kaasneva keskkonnamõju hindamise (KMH) aruanne.- OÜ Eesti Geoloogiakeskus, Tallinn.

Petrella, E., Capuano, P., Carcione, M. \& F. Celico, 2009: A high-altitude temporary spring in a compartmentalized carbonate aquifer: the role of low-permeability faults and karst conduits.- Hydrological processes, 23, 23, 3354-3364. DOI:10.1002/hyp.7454.

Raukas, A., 1997: Location and topography.- In: Raukas, A. \& A. Teedumäe (eds) Geology and Mineral Resources of Estonia. Estonian Academy Publishers, pp. 9-14, Tallinn.

Ravbar, N., 2013: Variability of groundwater flow and transport processes in karst under different hydrologic conditions.- Acta Carsologica, 42, 2-3, 327-338. DOI:10.3986/ac.v42i2.644.

Ravbar, N., Barbera, J. A., Petrič, M., Kogovšek, J. \& B. Andreo, 2012: The study of hydrodynamic behaviour of a complex karst system under low-flow conditions using natural and artificial tracers (the catchment of the Unica River, SW Slovenia).- Environmental Earth Sciences, 65, 8, 2259-2272. DOI:10.1007/s12665-012-1523-4 
Reed, T. M., McFarland, J. T., Fryar, A. E., Fogle, A. W. \& J. L. Taraba, 2010: Sediment discharges during storm flow from proximal urban and rural karst springs, central Kentucky, USA.- Journal of hydrology, 383, 3, 280-290. DOI:10.1016/j.jhydrol.2009.12.043.

Ryan, M. \& J. Meiman, 1996: An Examination of Short-Term Variations in Water Quality at a Karst Spring in Kentucky.- Ground Water, 34, 23-30. DOI:10.1111/j.1745-6584.1996.tb01861.x.

Savitski, L. \& V. Savva, 2008: Nabala lubjakivimaardla rajatavate karjääride mõju põhjavee seisundile.- OÜ Eesti Geoloogiakeskus, Tallinn, $36 \mathrm{pp}$.

Schmidt, S., Geyer, T., Guttman, J., Marei, A., Ries, F. \& M. Sauter, 2014: Characterisation and modelling of conduit restricted karst aquifers-example of the Auja spring, Jordan Valley.- Journal of Hydrology, 511, 750-763. DOI:10.1016/j.jhydrol.2014.02.019.

Smart, C. \& S. R. H. Worthington, 2004: Springs.- In: Gunn, J., (ed) Encyclopedia of Cave and Karst Science. Fitzroy Dearborn, pp. 1495-1504, London.

Smart, C. C., 1983: Hydrology of a Glacierised Alpine Karst Castlegaurd Mountain, Alberta.- PhD thesis. McMaster University, Hamilton, 343 pp.

Smith, B. A., Hunt, B. B., Andrews, A. G., Watson, J. A., Gary, M. O., Wierman, D. A. \& A. S. Broun, 2015: Surface water-groundwater interactions along the Blanco River of central Texas, USA.- Environmental Earth Science, 74, 12, 7633-7642. DOI:10.1007/ s12665-015-4630-1.
Sooäär, I., 1980: Harju rajooni J. Lauristini nim. kolhoos. Särge-Nõrava peakraavi rekonstrueerimine. Ehitusgeoloogia aruanne.- Tallinn.

Stevanović, Z., 2015: Characterization of Karst Aquifer.- In: Stevanović, Z., (ed) Karst Aquifers - Characterization and Engineering. Springer International Publishing Switzerland, pp. 47-126, Cham.

Suuroja, K., Ploom, K., Mardim, T., All, T., Kaljuläte, K., Kõiv, M. \& T. Vahtra, 2003: Eesti Geoloogilise baaskaardi Vaida (6341) seletuskiri.- OÜ Eesti Geoloogiakeskus, pp. 58, Tallinn.

Vallner, L., 2014: Karstinähtused kavandataval Nabala looduskaitsealal.- Eesti Loodus, 8, 13-19.

Vallner, L., 1996: Hydrogeological modelling of mine dewatering in the karstified Pandivere Upland, Estonia.- Proceedings of the Estonian Academy of Sciences. Geology, 45, 2, 53-67.

Zehe, E. \& M. Sivapalan, 2009: Threshold behaviour in hydrological systems as (human) geo-ecosystems: manifestations, controls, implications.- Hydrology Earth System Sciences, 13, 1273-1297. DOI:10.5194/hess-13-1273-2009. 